ARTIGO

\title{
A busca de um novo paradigma: política exterior, comércio externo e federalismo no Brasil
}

JOSÉ FLÁVIO SOMBRA SARAIVA*

Rev. Bras. Polit. Int. 47 (2): I 31 - 162 [2004]

\section{Introdução}

Apesar da sua juventude como experimento político dos últimos dois séculos, o federalismo - entendido como uma forma entre outras de estruturação da ordem política geograficamente distribuída - é tema que vem ganhando densidade crescente no estudo das relaçóes internacionais. Muito já se disse sobre o federalismo no Brasil e no mundo, mas recente e parco é o adensamento bibliográfico sobre a conexão extraordinária - que abre avenidas para o desenvolvimento das políticas exteriores dos Estados - entre os níveis distintos da autoridade política no interior de tais Estados e o meio internacional, de forma comparada.

$\mathrm{Na}$ literatura política moderna, o federalismo está associado à idéia de construção da unidade na variedade. A imagem do equilíbrio perfeito no seio da experiência republicana ocidental vem fazendo uso das vantagens do sistema federalista. Há os apaixonados pelo federalismo como há os que dele se afastam.

\footnotetext{
* Professor do Instituto de Relaçôes Internacionais da Universidade de Brasília (UnB) e diretorgeral do Instituto Brasileiro de Relaçôes Internacionais (IBRI).
} 
O objetivo do presente estudo é, portanto, contribuir para o entendimento das conexões entre a dimensão federativa do Estado brasileiro e as relaçōes internacionais do Brasil, com ênfase especial à política de comércio exterior. Embora política exterior e política de comércio exterior não sejam necessariamente equivalentes, uma não subsiste sem a outra, como demonstra a experiência histórica da América Latina. ${ }^{1}$

$\mathrm{Na}$ primeira parte do estudo, trata-se de propor a renovação dos marcos analíticos e paradigmáticos para o estudo do federalismo brasileiro no campo atinente às relações internacionais e comerciais do país. $\mathrm{Na}$ segunda parte, avaliam-se algumas das negociações comerciais em curso e prioritárias para o Brasil. Na terceira parte, avalia-se o peso relativo das secretarias e agentes subnacionais, em diferentes estados da federação, em sua ação externa no campo do comércio exterior. Ênfase é conferida à experiência do Estado do Ceará, uma das unidades subnacionais mais ativas no incremento de relações comerciais externas, apesar de sua relativamente modesta histórica contribuição à pauta exportadora do Brasil. Nas conclusões faz-se o balanço e sugerem-se alguns conceitos e políticas para o aperfeiçoamento dessa dimensão federativa da política de comércio exterior do Brasil.

\section{Renovando os marcos analíticos do estudo do federalismo brasileiro no campo atinente às relações internacionais e comerciais}

Há que se fazer ressaltar a necessidade de uma profunda revisão dos paradigmas que orientam as relações internacionais dos estados federativos. Esse movimento vem acontecendo, em escala diferenciada, em todo o mundo e expressa a elevação gradual de status quo dos entes federativos ou das unidades subnacionais no processo de gestação das relações internacionais do mundo contemporâneo.

No caso brasileiro, a chamada paradiplomacia dos entes federativos vem demonstrando vigor excepcional nos últimos anos, sinalizando

\footnotetext{
${ }^{1}$ Leituras contemporâneas e comparadas das relações entre regime político dos Estados e política exterior, bem como suas implicaçôes para as políticas de comércio exterior foram por mim editadas no livro: SARAIVA, José Flávio S. (ed). Foreign Policy and Political Regime. Brasília: Instituto Brasileiro de Relaçôes Internacionais (IBRI); 2003.
} 
fenômeno original na conformação do processo decisório da política exterior e comercial do país. Inédita é a introdução de um certo "federalismo social", em torno do qual a autoridade política descentralizada atua mais próxima às realidades e interesses socialmente constituídos. Essa nova dimensão, que emerge na base das transformaçóes que ocorrem nos planos mais locais da vida federativa, vem impregnando positivamente a gestão do estado.

A percepção acima descrita não quer dizer, de forma automática, que o federalismo brasileiro tenha avançado de forma célere nos últimos anos. Ao contrário, o Brasil é um exemplo extraordinário de descompasso entre os aspectos formais e reais, no que tange à dimensão da ação externa dos entes federativos. Há quase um abismo entre palavras e gestos.

A criação, no Ministério das Relações Exteriores, apenas em 1997, de uma divisão específica para tratar dos interesses e assuntos federativos, expõe o quanto o assunto chegou tarde à chancelaria. A então Assessoria de Relações Federativas não chegou a possuir status elevado no processo decisório do Itamaraty, até sua fusão mais recente com os assuntos parlamentares em outra assessoria criada mais recentemente: a Assessoria Especial de Assuntos Federativos e Parlamentares. ${ }^{2}$ Nomeou-se, para a Embaixada do Brasil em Buenos Aires, em 2004, um diplomata para cuidar das articulaçõoes federativas do Brasil naquele país.

A instalação, nos primeiros meses do governo Lula, de uma Subchefia de Assuntos Federativos na própria Presidência da República, vem permitindo engendrar movimentos políticos inéditos. Seu titular, Vicente Trevas, já conseguiu alcançar um lugar mais visível na articulação e no gerenciamento de projetos cooperativos na área internacional, como nos casos de interlocução de prefeituras de cidades paulistas com cidades italianas da Planície do Pó. Uma outra iniciativa da subchefia vem sendo o esforço da aproximação desse novo lugar estratégico, próximo ao presidente da República, com as assessorias e secretarias de assuntos internacionais dos entes federativos. ${ }^{3}$

\footnotetext{
2 Vale, no entanto, reconhecer avanços recentes do Itamaraty na matéria como a criação, em 2004, na Embaixada do Brasil e Buenos Aires, de um setor para tratar das relaçóes da própria embaixada com as províncias argentinas.

${ }^{3}$ A organização do seminário, Primeira Reunião de Operadores Estaduais sobre Cooperação Internacional Federativa, em auditório do Palácio do Planalto, com os secretários e assessores
} 
De onde se originam as dificuldades do federalismo brasileiro? Da história nacional, que quase sempre oscilou entre avanços normativos e contenções práticas de reação à autonomia dos entes federativos. Essa tensão pareceria superada a partir de 1988, ante a inovação jurídica que emergiu no quadro da democratização do país. A Constituição brasileira inovara em relação aos demais sistemas republicanos federativos. A forma federalista tornou-se cláusula pétrea, tornando-a impossível de ser objeto de proposta de emenda que tente aboli-la. ${ }^{4}$ Os municípios fizeram-se membros da federação e passaram a ter autonomia política, jurídica e administrativa em relação ao governo federal. Constituições dos Estados-membro foram escritas em nome dessa autonomia. E, até segunda ordem, a Constituição de 1988 reservou aos Estados-membro da federação todas as demais competências que não lhes são vedadas pela própria lei maior. ${ }^{5}$

A novidade jurídica da "relativa autonomia" das municipalidades e da "semi-autonomia"6 dos estados da federação - muito embora ambas as formas de autonomia jamais tivessem sido pensadas como desvinculadas do conceito paralelo de "cooperação" com a União - foi digna de nota na

internacionais dos estados membros da federação, no dia 12 de fevereiro de 2004, foi uma extraordinária iniciativa da Subchefia de Assuntos Federativos. Na ocasião, o deputado Aldo Rebelo, ministro secretário da Coordenação Política e Assuntos Institucionais, pronunciou discurso propondo a cooperação mais ativa do governo federal com os entes federativos na cena internacional. Também vale lembrar a iniciativa do Primeiro Seminário sobre Coordenação Federativa para a Promoção de Exportaçōes, organizado pela subchefia referida, em associação ao Ministério do Desenvolvimento, Indústria e Comércio Exterior e ao Ministério das Relações Exteriores, no dia 9 de novembro de 2004, no auditório da Presidência da República, no anexo 1 do Palácio do Planalto.

${ }^{4}$ BRASIL. Constituição (1988). Constituição da República Federativa do Brasil: promulgada em 5 de outubro de 1988. Organização do texto: Juarez de Oliveira. 4 ed. São Paulo: Saraiva, 1990. Artigo 60, parágrafo 4, inciso IV.

${ }^{5} \mathrm{Idem}$. artigo 20, parágrafo 1.

${ }^{6}$ Os conceitos de "relativa autonomia" das municipalidades e de "semi-autonomia" dos Estadosmembro da federação foram por mim desenvolvidos na conferência pronunciada na Primeira Reunião de Operadores Estaduais sobre Cooperação Internacional Federativa, organizada pela Subchefia de Assuntos Federativos da Secretaria de Coordenação Política e Assuntos Institucionais da Presidência da República, no dia 12 de fevereiro de 2004. No primeiro caso, refiro-me aos espaços de manobra consolidados na Constituição de 1988 para os municípios de menor autonomia que o compartilhamento semi-autônomo dos Estados-membro da federação, que constroem a base da governança política do Estado nacional pela via da representação direta no Senado Federal e pela Câmara dos Deputados. Ademais, o espaço de manobra dos governadores se faz de forma bem mais expressiva que a dos mais de cinco mil prefeitos brasileiros. 
literatura internacional e apreciada pelos federalistas viscerais. Estudiosos de todo o mundo debruçavam-se sobre essa crescente autonomia das municipalidades, do poder local e do poder dos estados da federação e das regiões brasileiras.

Naquele momento, em que os ventos democráticos fariam supor a construção do equilíbrio natural entre as três bases do Estado federativo, sonhou-se com a idéia de que haveria uma simbiose natural entre funções, deveres e responsabilidades. Pareceria que municípios e estados brasileiros emergiam frente aos constrangimentos da União para um nirvana no qual quase tudo se podia fazer. Da arrecadação dos impostos à autonomia na utilização de parcela relativa do arrecadado, passando pela capacidade de empreender no campo da educação e da saúde, aliviando a União da sua centralidade jurídica e prática; todos esses campos de ação das unidades subnacionais proviam a idéia de um certo federalismo social no Brasil.

Não foi bem isso o que aconteceu. A evolução da 'autonomia relativa' e da 'semi-autonomia' cooperativas se fez de forma atabalhoada. Estados e municípios foram acuados pelo poder central, acusados de terem contraído dívidas e não poderem pagar. Moratórias estaduais e municipais foram freqüentes. Choques entre coalizões políticas diferenciadas entre o poder central e os entes federativos criariam ampla frente de tensão, com exemplos que podem ser citados a exaustão. $\mathrm{O}$ acumulado de quase duas décadas de crescimento econômico baixo, bastante aquém das possibilidades históricas da economia brasileira, aceleraram o Estado de natureza fratricida que se estabeleceu.

Duas vias se impuseram na recente quadratura da história do federalismo brasileiro inconcluso. A primeira foi o choque de recentralização clássica, via reconcentração das responsabilidades da gerência do Estado nacional. Instrumentos como as reformas previdenciária e tributária, já no governo Lula, bem como a chamada Lei de Responsabilidade Fiscal, aprovada no governo Cardoso, expõem o quanto o Brasil centralizou matérias de interesse estratégico, apesar da propalada defesa do chamado "pacto federativo".

A segunda via de constrangimento do federalismo esgarçado do Brasil vincula-se, mais precisamente, ao universo das relações internacionais. O tratamento economicista ortodoxo, no coração do poder político da União, da dívida externa do país contraída no passado, mas 
acelerada a partir do processo desenfreado de liberalização comercial e financeira ocorrida no Brasil nos anos 90, de Collor de Mello a Cardoso, fez do Tesouro e do Banco Central, as células pulsantes e propulsoras do controle central rígido da chamada "estabilização monetária". A conta social elevada gerada pela alta crescente da taxa de juros, embora comova a todos, em especial àqueles que militam em favor de um projeto federativo social mais ativo - em torno de programas de alívio e erradicação da pobreza e da fome, por exemplo - continua sendo tratada de forma conservadora e centralizada no governo central.

A adoção com baixo senso crítico dos ditames do Consenso de Washington e a abertura dos braços aos riscos da globalização assimétrica, especialmente aquela gerada pelo regime de fluxos financeiros instáveis e gananciosos, foram o golpe final contra o esforço de construção de certa autonomia relativa dos entes federativos e inibidor de um verdadeiro federalismo social e cooperativo. $\mathrm{O}$ tratamento de todas essas matérias foi - e segue sendo - fortemente concentrado na União.

A mobilização de esforços no sentido da consecução de superávits fiscais de agrado do FMI contaminou, em muitos casos, as relaçôes do poder central com governos subnacionais. A declaração unilateral de moratória do governador do Estado de Minas Gerais, Itamar Franco, em 1999, foi emblemático das dificuldades entre a União e alguns governos subnacionais no Brasil.

Quais as conseqüências desse ambiente político e institucional para o tema do federalismo e das relaçôes internacionais do Brasil? Qual o impacto dessas formas de inserção internacional para as políticas de comércio exterior?

Apesar dos avanços jurídicos de 1988, impera no Brasil a visão démodé, mas suficientemente cristalizada nas elites nacionais, de que a única voz válida é a voz unitária do Estado. O Estado central - por meio dos vitoriosos nas coalizôes no governo central, ao lado dos grupos controladores do aparato de funcionamento de suas instituições, acompanhados pelas resistências corporativas das burocracias que se afirmam, via a força da "pena" e da "alocação de recursos" - não aprecia a idéia da fragmentação da autoridade nas questões internacionais. A tese da iminência do descontrole interno e a hipótese das dificuldades que emanariam da descentralização coordenada na formulação de políticas 
públicas com impacto internacional são comuns na burocracia federal, particularmente do Itamaraty e do Banco Central. A idéia da formulação pela coordenação da diversidade de interesses do federalismo social, a envolver as unidades subnacionais, recebe ainda forte reação contrária do poder central.

Esse senso comum vem, no entanto, enfrentando invulgar resistência daqueles que, operando em um ambiente internacional cada vez mais confuso e complexo, provocam o abalo do paradigma tradicional da voz unitária do Estado-nação. O conceito de "Estado logístico" - que vem ganhando força como um novo paradigma na política exterior do governo Lula - vem provendo os processos decisórios de política comercial com um inédito senso de realismo e de oportunidade, que implica maior mobilização interna dos entes federativos. ${ }^{7}$ A formação de coalizões internacionais ao Sul - como aquela pragmática e realista frente de interesses da qual emanou, na Conferência da OMC em Cancun, o Grupo dos 20 (G20), bem como a parceria do G3 ou IBSA (Índia, Brasil e África do Sul) - demanda mais ação concertada no plano interno dos Estados entre os entes federativos e o poder central.

Os resultados práticos da mais recente rodada de negociações da OMC, em Genebra, (julho-agosto de 2004), - da qual a Índia e o Brasil verbalizaram os anseios e as preocupações do G20, no que se refere ao acesso aos mercados do Norte - ao desentravarem os impasses de Cancun, demonstra a abertura que vem sendo feita nessa área por tais coalizões internacionais ao Sul. ${ }^{8}$ Mas elas não terão sustentação se não por um uma via mais participativa dos entes federativos no interior dos Estados nacionais. Essa é uma percepção que começa a se espraiar com mais convicção no Brasil.

A mudança de paradigma se faz necessária. $\mathrm{O}$ conceito tradicional de soberania estatal é posto em xeque, ao permitir engendrar a revitalização de áreas incontestavelmente ligadas a interesses e cooperações com as unidades subnacionais. Esse é o caso da política comercial do Brasil

\footnotetext{
7 CERVO, Amado L., Relações Internacionais do Brasil: um balanço da era Cardoso. Revista Brasileira de Política Internacional, ano 45, v.1. Brasília: Instituto Brasileiro de Relações Internacionais, 2002, p. 5-35.

${ }^{8}$ SARAIVA, José Flávio S. Lula, África e OMC na crítica de direita. O Povo. 8 de agosto de 2004, p. 34.
} 
para a formação de um grande mercado sul-americano de intercâmbios, bem como da expansão do comércio Sul-Sul, à maneira que vem sendo postulado pelo núcleo duro de poder nacional na formulação da política exterior bem como da política comercial do país.?

Como ampliar o comércio com os países da franja oriental do Atlântico Sul sem a força da diversidade operacional e da capacitação de operadores da cooperação internacional nos estados e municípios? Como agir na transformação dos padrões obsoletos de um comércio internacional com logística precária, - por exemplo, exporta apenas cerca de $8 \%$ das suas tão relevantes exportações por mar em navios nacionais - sem envolver uma indústria de estaleiros sustentável em parceria com os entes federativos? Como exportar mais carne de frango para a China, sem uma base de informação de oportunidades e capacidade gerencial e técnica na base, nos estados da federação particularmente, capazes de operar as máquinas de exportação? Vamos entregar o processo exportador apenas a grupos transnacionais e oligopólios que agem diretamente no Estado central, a obterem prebendas e acessos a subsídios para a exportação de suas subsidiárias para suas próprias matrizes no coração da hegemonia capitalista?

Ante esse quadro, faz-se mister envolver os governos subnacionais de forma cooperativa, mas a reconhecer-lhes sua "relativa autonomia". $\mathrm{O}$ paradigma estatocêntrico inicia, apenas recentemente, seu processo de erosão. A ampliação da pauta exportadora, mecanismo a mais de constituição de poupança e meio de contenção do financiamento interno via capitais perniciosos, é tarefa que não pode se restringir ao Estado central. Essa brecha inédita e relevante para o comércio exterior do Brasil vem sendo explorada pelos estados da federação, apesar dos constrangimentos jurídicos e operacionais.

Os estados da federação passaram a reivindicar seu lugar na agenda do comércio exterior. Essa reivindicação adquire, de forma crescente,

\footnotetext{
${ }^{9}$ Ver, em especial, o discurso do presidente Lula no balanço apresentado na V Reunião de Chefes de Governo e de Estado da Comunidade de Países de Língua Portuguesa, em São Tomé e Príncipe, em 26 de julho de 2004. Na ocasião, o presidente chamou a atenção para o fato de que os marcos das novas negociaçôes globais, das quais o G3 participava também incluíam as demandas de países de desenvolvimento relativo mais baixo e agentes múltiplos mais além do Estado nacional e dos seus agentes tradicionais.
} 
eco e interesse em Estados nacionais continentais como o Brasil, cuja territorialidade extensa acrescenta valor ao desejo de mais flexibilização nessa matéria. Governadores de estados vêm sublinhando que seus interesses são bastante diversos e o quanto essa diversidade deve ser considerada na formulação da política exterior e comercial.

Ganha força no Brasil, a diplomacia de múltiplas camadas, exercida em diferentes níveis do processo decisório. A high politics, encaminhada pela diplomacia estatal clássica do Itamaraty, aceita e acata, mas também reage e convive de forma cooperativa, com a diversidade da low politics, espaço natural dos entes subnacionais. Na acepção de Barros Leal Farias, que estudou de forma pioneira o caso brasileiro, a paradiplomacia federativa vem crescendo, ainda que de forma discreta. ${ }^{10}$ Nesse aspecto, reconhece a estudiosa, a tendência já sugerida por Panayotis Soldatos e Ivo Duchacek, para quase todo os quadrantes do planeta, onde há experiência de estados federativos. ${ }^{11}$

Nesse sentido, o novo paradigma da valorização dos entes subnacionais coincide com a emergência do paradigma do Estado logístico no Brasil. O Estado logístico, ao procurar expor a vontade de fortalecer o núcleo nacional da ação externa do Brasil, passa a operar diretamente na transferência à sociedade da responsabilidade empreendedora, ajudando-a a atuar no ambiente externo. A busca por um melhor modo de equilibrar os benefícios da interdependência por meio de uma inserção madura no mundo globalizado é o elemento aglutinador das posições e opções. $\mathrm{O}$ esforço do governo Lula em romper os graus da interdependência servil em favor de uma interdependência de oportunidades não poderá se afastar do desiderato da valorização dos mecanismos federativos que já estão garantidos, em parte, nos textos jurídicos.

\footnotetext{
${ }^{10}$ FARIAS, Déborah Barros Leal. Os Estados-Membro no Federalismo Brasileiro. Idéias \& Debate, n. 20, agosto de 2000; FARIAS, Déborah Barros Leal. Federalismo e Relaçôes Internacionais, 2000. Dissertação de mestrado - Programa de Pós-graduação em Relações Internacionais, Universidade de Brasília, Brasília.

11 DUCHACEK, Ivo. Perforated Sovereignties: Towards a Typology of New Actors in International Relations. In: MICHELMANN, Hans \& SOLDATOS, Panayotis. Federalism and International Relations: the role of subnational units. Oxford: Clarendon Press, 1990, p. 1-33; SOLDATOS, Panayotis. An Explanatory Framework for the Study of Federaated States as Foreign-policy Actors. In: MICHELANN, Hans \& SOLDATOS, Panayotis, op. cit., p. 34-53
} 


\section{Os marcos das negociações comerciais em curso do Brasil: entre o poder do Estado nacional federativo logístico e a diversidade de interesses em jogo}

A carga de negociações comerciais externas do Brasil vem se ampliando nos últimos anos. O leque de parcerias também se diversificou nos últimos quatro anos, após o retraimento da condição brasileira de global-trader, marca dos anos 70 e parte dos anos 80 . O recolhimento na década de 1990 esteve visivelmente associado à crise do modelo de inserção internacional do nacional-desenvolvimentismo. ${ }^{12}$

No período mais recente, relativo aos últimos anos do governo Cardoso e o início do governo Lula, tanto parceiros estratégicos já consagrados como a Argentina, o México ou a África do Sul, assim como novos e crescentes sócios na mesma latitude, como a Índia e a China, vêm ganhando densidade na pauta comercial do Brasil. O plano das relações bilaterais vem sendo reforçado por meio da articulação de uma visão mais realista das relações internacionais e do distanciamento em relação sonhos kantianos de uma ordem internacional reformada pela governança global liberal, falha já nos fins dos anos 90 .

O governo Lula, nesse caso, se aproxima mais do conceito de Estado logístico no qual o comércio exterior tem peso extraordinário. O conceito de Estado logístico supõe a superação tanto do modelo de inserção liberal desenfreada quanto do desenvolvimentismo nacionalista de antes. Por esse paradigma, o repasse de responsabilidades do Estado- empresário cabe mais à sociedade bem como aos agentes subnacionais. Essa estratégia não significa, no entanto, o rechaço ao empreendimento estatal, desde que este apresente capacidade de construir competitividade sistêmica global. São dois os componentes da formulação logística posta em marcha: por um lado, advoga-se a construção dos meios de poder e, por outro, sua

\footnotetext{
12 Para o tema do modelo do nacional-desenvolvimentismo e a política exterior e comercial do Brasil, ver em especial, CERVO, Amado \& BUENO, Clodoaldo, História da Política Exterior do Brasil, Brasília: Editora da UnB/Instituto Brasileiro de Relações Internacionais, 2000, e, MACHADO, Heloísa, A política comercial do Brasil, 2003. Tese de doutorado - Programa de Pós-graduação em História das Relações Internacionais, Universidade de Brasília, Brasília.
} 
utilização para fazer valer vantagens comparativas de natureza intangível, como a ciência, a tecnologia e a capacidade empresarial. ${ }^{13}$

Isso significa dizer que as negociações comerciais multilaterais mantidas pelo Brasil têm um sentido mais sistêmico e menos conjuntural. Elas estão voltadas para a superação da dependência estrutural em relação aos fluxos financeiros voláteis internacionais e orientadas para a superação da crise de financiamento e poupança internas. Ademais, orientam-se politicamente no sentido de refrear, por meio da construção de novas estruturas anti-hegemônicas bem diferentes do velho idealismo Sul-Sul, um novo patamar para a negociação dos interesses comerciais Sul-Sul. ${ }^{14}$ O relançamento da chamada "política africana" do Brasil pelo governo Lula tem, evidentemente, a marca da retomada do braço sul-atlântico do comércio internacional do Brasil, apesar da retórica recursiva da "africanidade brasileira" ${ }^{15}$

Estão, de fato, em jogo interesses vitais para o Brasil uma vez que sem um crescimento exponencial das exportaçôes, a armar um superávit expressivo na balança comercial, permanecerá o país condenado à vulnerabilidade econômica. É evidente que o histórico de diversificação de parcerias, tanto ao Sul quanto ao Norte, ajuda muito a desbravar o redescobrimento de novas fronteiras comerciais. $\mathrm{O}$ caso da presença chinesa nas relações comerciais do Brasil é fenômeno que vem sendo registrado com grande regozijo pelos setores exportadores e pelo governo central, mas também por governos subnacionais, como os estados do

\footnotetext{
${ }^{13}$ CERVO, Amado, Política exterior e relações internacionais do Brasil: enfoque paradigmático. Revista Brasileira de Política Internacional, ano 46, v. 2. Brasília: Instituto Brasileiro de Relações Internacionais, 2003, p. 22.

14 A respeito da onda anterior de transformação da assimetria econômica internacional organizada pela chamada "frente dos povos atrasados", nos anos 1970 e 1980, bem como seus escassos impactos na transformação aos entraves ao comércio internacional das nações em desenvolvimento, ver: SARAIVA, José Flávio S. Détente, diversidade, intranqüilidade internacional e sonhos igualitaristas. In: SARAIVA, José Flávio S. Relações Internacionais Contemporâneas - dois séculos de história. vol II. Brasília: Instituto Brasileiro de Relações Internacionais; Funag; 2001.

${ }^{15}$ SARAIVA, José Flávio S. Política exterior do Governo Lula: o desafio africano. Revista Brasileira de Politica Internacional, ano 45, v.2. Brasília: Instituto Brasileiro de Relações Internacionais, 2002, p. 5-25.
} 
sul do Brasil, Paraná, Santa Catarina e Rio Grande do Sul. ${ }^{16}$ Em vários desses casos as compras chinesas vêm sendo feitas ao lado de negociaçôes de investimento. ${ }^{17}$

O caso do agronegócio brasileiro ocupa papel todo especial à inserção internacional do Brasil nas regras duras do comércio internacional. A área disponível para novos plantios é equivalente ao território somado de vários países europeus. Desde 1990, em plena segunda década perdida, a safra de grãos aumentou em torno de $125 \%$, enquanto a área plantada cresceu menos de um quarto.

Aspecto essencial nas últimas negociações da OMC, em Genebra, o Brasil vem se habilitando como um dos maiores produtores e exportadores de produtos agrícolas do mundo. O acordo firmado em Genebra vai significar aumento de aproximadamente US\$ 10 bilhões nas vendas de produtos brasileiros ao exterior, segundo estimativas do ministro das Relações Exteriores Celso Amorim, baseada na redução gradual e na eliminação de subsídios agrícolas à exportação praticados pelos países ricos. A dramaticidade das reuniões em Genebra, na primeira semana de agosto de 2004, mostraram o quanto se ganhou nesta área. Como lembrou o chefe da Missão brasileira na OMC, o embaixador Luiz Felipe de Seixas Corrêa:

\footnotetext{
${ }^{16}$ Vale lembrar que o Brasil, desde os anos 60, mais claramente forma mais nítida a partir da década seguinte, vem mantendo uma matriz tríptica de diversificação do seu comércio exterior. Praticamente um quarto do comércio exterior global do Brasil vem sendo com os Estados Unidos da América, mas quase sempre inferior à tendência de manutenção de cerca de um terço desse mesmo comércio com a Europa e um outro um quarto com a América Latina, em especial ante criação do Mercosul e da parceria estratégica com a Argentina. O percentual restante vem se diversificando bastante com os continentes africano e asiático. A China vem despontando como um parceiro comercial crescentemente importante para o Brasil. Nesse caso, o espetacular crescimento da exportação de carne de frango e de soja para a China fez do Brasil o mais importante parceiro comercial daquele país na América Latina e um dos três primeiros parceiros comerciais do Brasil no ano de 2003, depois dos EUA e da Argentina. Segundo dados divulgados pela Associação Brasileira de Produtores e Exportadores de Frango (Abef), foram embarcadas 238.270 toneladas de carne de frango para a China, em junho de 2004, a maior da história, tanto em volume como em faturamento, com alta de $53 \%$ sobre o mesmo mês em 2003. Em receita cambial, as exportações desse produto para aquele país atingiram US\$ 248 milhões, $85 \%$ acima do faturado em junho de 2003.

${ }^{17}$ Um bom exemplo disso é caso dos empresários chineses que estão negociando com cooperativas paranaenses, por meio da Organização das Cooperativas do Paraná (Ocepar), a construção ou aquisição de silos próprios no Porto de Paranaguá, assim como financiamento para que os agricultores possam comprar fertilizantes ou troca desse insumo pela soja. Ver: China estuda investimento, Correio Braziliense. 14 de julho de 2004, p. 10, Brasília.
} 
"Não basta mais o consenso entre americanos e europeus. Há uma nova matriz, o G2O. Essa coalizão não se limita a criticar ou obstruir. Tem propostas concretas. Espero que a mudança seja permanente." ${ }^{18}$

Alguns criticam a concentração da negociação externa e mesmo da pauta exportadora brasileira no agronegócio. Argumentam o fato de o país estar regredindo ao modo do comércio internacional do Brasil do século XIX, ante a ênfase agroexportadora. Outros insistem que essa foi uma brecha estratégica bem construída por setores dinâmicos da exportação nacional, mesmo sem grande apoio logístico do Estado. Uma terceira linhagem de intérpretes anota o fato de que programas como o Moderfrota, um programa do governo federal de apoio à modernização das máquinas agrícolas via juros baixos, ter permitido renovar, nos últimos anos, um terço da frota de tratores e quase metade das colheitadeiras no país. Em certa medida, o Estado central esteve atuando fortemente na readequação desse setor à competitividade internacional.

O fato é que esse setor, envolvendo toda a cadeia produtiva, do plantio à comercialização, deve movimentar, até o final de 2004, cerca de R \$ 537,7 bilhôes, cerca de um terço do Produto Interno Bruto (PIB). Emprega 18 milhões de brasileiros (cerca de 38\% da força de trabalho) e representa $42 \%$ das exportações nacionais, algo em torno de $\mathrm{R} \$ 90$ bilhões. Esse desempenho é, sem margem de dúvida, resultado direto do investimento pesado em ciência e tecnologia. Os novos dados são animadores: o faturamento com a venda de soja no mercado externo em 2003, por exemplo, injetou R \$ 24 bilhões na economia brasileira; em junho de 2004, as exportações do agronegócios totalizaram US \$ 4,4 bilhões, um recorde histórico mensal; em doze meses, com exportações de US \$ 35,5 bilhões, o saldo comercial do agronegócios superou pela primeira vez a cifra de US $\$ 30$ bilhões. ${ }^{19}$

Os avanços nos setores citados, no entanto, embarram em estruturas de negociação particularmente burocratizadas e centralizadas no governo central. Sob a coordenação do Itamaraty, do Ministério da Agricultura e do Ministério do Desenvolvimento, Indústria e Comércio Exterior

\footnotetext{
${ }^{18}$ Negociações de US\$ 10 bilhões. Correio Braziliense. Brasília, 8 de agosto de 2004.

19 ALBERTO JR., Carlos. O agronegócio vai nos salvar?. Correio Braziliense. Brasília, 12 de julho de 2004, p. 8.
} 
(MDIC), em especial da Secretaria de Comércio Exterior - esta última sob a direção do secretário Ivan Ramalho - e da própria SecretariaExecutiva - sob a supervisão do secretário Márcio Fortes - as negociaçōes, tanto no plano bilateral quanto no multilateral, são conduzidas por mecanismos de coordenação entre essas áreas do governo central, sem envolvimento direto das secretarias de comércio e de desenvolvimento das unidades sub-nacionais.

$\mathrm{O}$ argumento crucial dos negociadores internacionais da União, ávidos para manterem a verticalidade dessa plataforma negocial, está no fato de que o emaranhado e a complexidade das várias negociações simultâneas exige coordenação central. Nesse sentido, a Câmara de Comércio Exterior (Camex) já seria suficiente como lugar de interação dos atores domésticos no processo interno de circulação de informações e tomada de decisões. Se esse argumento é dotado de grande racionalidade e plausibilidade, o mesmo tem servido para reforçar o caráter centralista e estatocêntrico das negociações.

Adepto do livre comércio, do multilateralismo como padrão de conduta nas relaçóes internacionais e, portanto, preocupado com a consolidação da OMC, para levar adiante a Agenda de Desenvolvimento de Doha, o Brasil vem, certamente, desenvolvendo uma apropriada diplomacia comercial. Ao propugnar pela criação do G-20, na base da primeira grande coalizão de países emergentes com peso nas negociações comerciais multilaterais, o Brasil avança no sentido de se afastar das frustrações anteriores como a rodada comercial do Uruguai ou os entendimentos nefastos de Blair House.

Nesse sentido, como demonstrou mais recentemente a reunião de Genebra, a Conferência da OMC de Cancun não foi um fiasco, como apregoado por alguns, mas uma vitória política da diplomacia brasileira e dos países do Sul preocupados em manter espaço para a sua própria industrialização soberana e em criar estruturas mais duradouras que contenham a liberalização comercial de curso único. $\mathrm{O}$ tema dos subsídios agrícolas concedidos pelos países do capitalismo avançado foi apenas a ponta do iceberg para a constituição de certas estruturas antihegemônicas ao Sul.

No entanto, mais uma vez, essa grande negociação internacional - que envolve relevante concertação no plano interestatal - foi criticada 
por setores domésticos no Brasil ante a tênue consulta interna, a baixa agilidade de interlocução entre os setores públicos e privados, bem como pelo baixo envolvimento, na coordenação de posiçôes, de atores sub-nacionais. Apesar dos talentos negociadores do chanceler Celso Amorim bem como do ministro Furlan, do Desenvolvimento, Indústria e Comércio Exterior, permanece o déficit de consulta institucional e envolvimento das secretarias estaduais de desenvolvimento e comércio nessas matérias.

Outro déficit que se projeta de forma clara no comércio exterior do Brasil é sua assimetria interna. Concentra-se o comércio externo em certas unidades subnacionais em detrimento de outras. Concentramse as exportações nacionais em certas regiōes em desfavor de outras. Essa tendência, que embora tenha mudado ligeiramente no início da nova década, foi tendência histórica da industrialização brasileira concentrada no sul e no sudeste - e da expansão também concentradora do agronegócio. A tabela I indica o algo grau de assimetria regional das exportações nacionais em alguns anos da década passada. Quando comparada à atual, não houve ainda modificação substantiva no global, muito embora algumas novas tendências possam ser observadas para certos Estados mais empreendedores nessa área.

\section{Tabela I}

As exportações globais do Brasil por região e unidade subnacional Exportações brasileiras - valor e participação percentual estados e regiões (1996-1999, em milhões de dólares)

\begin{tabular}{l|l|l|l|l|l|l|l|l}
\hline Estados/Regiões & 1996 & $\%$ & 1997 & $\%$ & 1998 & $\%$ & 1999 & $\%$ \\
Total & 47.746 & 100 & 52.990 & 100 & 51.119 & 100 & 48.011 & 100 \\
Centro Oeste & 1.381 & 2,8 & 1.793 & 3,3 & 1.209 & 2,3 & 1.294 & 2,6 \\
DF & 30 & 0,0 & 8 & 0,0 & 4 & 0,0 & 9 & 0,0 \\
Goiás & 387 & 0,8 & 475 & 0,8 & 381 & 0,7 & 325 & 0,6 \\
Mato Grosso & 659 & 1,3 & 927 & 1,7 & 649 & 1,2 & 741 & 1,5 \\
Mato Grosso do Sul & 305 & 0,6 & 383 & 0,7 & 175 & 0,3 & 218 & 0,4 \\
Nordeste & 3.851 & 8,0 & 3.955 & 7,4 & 3.713 & 7,2 & 3.355 & 6,9 \\
Maranhão & 681 & 1,4 & 744 & 1,4 & 635 & 1,2 & 662 & 1,3 \\
Piauí & 62 & 0,1 & 61 & 0,1 & 58 & 0,1 & 49 & 0,1 \\
Ceará & 380 & 0,7 & 353 & 0,6 & 354 & 0,6 & 371 & 0,7 \\
Rio Grande do Norte & 94 & 0,1 & 93 & 0,1 & 101 & 0,1 & 115 & 0,2 \\
Paraíba & 103 & 0,2 & 86 & 0,1 & 54 & 0,1 & 6,2 & 0,1 \\
Pernambuco & 341 & 0,7 & 372 & 0,7 & 362 & 0,7 & 265 & 0,5 \\
& & & & & & & \multicolumn{2}{c}{ Continua... }
\end{tabular}




\begin{tabular}{l|l|l|l|l|l|l|l|l} 
Alagoas & 289 & 0,6 & 340 & 0,6 & 290 & 0,5 & 224 & 0,4 \\
Sergipe & 55 & 0,1 & 39 & 0,0 & 31 & 0,0 & 21 & 0,0 \\
Bahia & 1.846 & 3,8 & 1.867 & 3,5 & 1.828 & 3,5 & 1.581 & 3,2 \\
Norte & 2.398 & 5,0 & 2.568 & 4,8 & 2.587 & 5,0 & 2.677 & 5,5 \\
Acre & 2 & 0,0 & 0 & 0,0 & 0 & 0,0 & 1 & 0,0 \\
Rondônia & 27 & 0,0 & 37 & 0,0 & 37 & 0,0 & 55 & - \\
Amazonas & 143 & 0,2 & 193 & 0,3 & 266 & 0,5 & 429 & 0,8 \\
Pará & 2.117 & 4,4 & 2.263 & 4,2 & 2.207 & 4,3 & 2.135 & 4,4 \\
Amapá & 101 & 0,2 & 64 & 0,1 & 62 & 0,1 & 45 & 0,0 \\
Roraima & 7 & 0,0 & 2 & 0,0 & 2 & 0,0 & 1 & 0,0 \\
Tocantins & 1 & 0,0 & 9 & 0,0 & 13 & 0,0 & 8 & 0,0 \\
Sudeste & 26.703 & 55,9 & 29.599 & 55,8 & 29.996 & 58,6 & 28.011 & 58,3 \\
São Paulo & 16.575 & 34,7 & 18.092 & 34,1 & 18.219 & 35,6 & 17.541 & 36,5 \\
Rio de Janeiro & 1.884 & 3,9 & 1.734 & 3,2 & 1.782 & 3,4 & 1.640 & 34 \\
Espírito Santo & 2.454 & 5,1 & 2.547 & 4,8 & 2.407 & 4,7 & 2.447 & 5,0 \\
Minas Gerais & 5.790 & 12,1 & 7.226 & 13,6 & 7.588 & 14,8 & 6.382 & 13,2 \\
Sul & 12.545 & 26,2 & 13.930 & 26,2 & 12.456 & 24,3 & 11.498 & 23,9 \\
Paraná & 4.245 & 8,8 & 4.854 & 9,1 & 4.227 & 8,2 & 3.932 & 8,1 \\
Santa Catarina & 2.637 & 5,5 & 2.805 & 5,2 & 2.601 & 5,0 & 2.567 & 5,3 \\
Rio Grande do Sul & 5.663 & 11,8 & 6.271 & 11,8 & 5.628 & 11,0 & 4.998 & 10,4 \\
\hline
\end{tabular}

Fonte: IBGE, Anuário Estatístico do Brasil, 1996 a 1999 (Elaborada por Wilson Almeida)

Finalmente vale lembrar que o novo ativismo comercial do Brasil, que encontra algum paralelo com o modelo do nacional-desenvolvimentismo, relegado em período mais recente da história nacional, encontra inédito paralelismo com o ativismo comercial engendrado na última década por países da América Latina, como o Chile e o México, sobre as diferenças de conceito e de proporcionalidade, pautadas em cada caso, e as relações externas desses países. Refiro-me às estratégias de inserção comercial internacional baseadas na firme aposta nas negociações de acordos de livre-comércio com importantes parceiros sub-regionais como a Comunidade Andina, a União Européia e a Área de Livre Comércio da América (Alca), neste caso com menos intensidade e mais cautela negocial. Vale, nesse caso, a lembrança de Costa Vaz:

Para muitos países, a exemplo daqueles que integram o Mercosul, essa condição observada nos últimos anos lhe permitira perseguir estratégia de explorar condições de barganha, baseando-se em uma visão integrada dos diferentes tabuleiros em que estejam atuando, como exemplificado 
no caso das perspectivas do Mercosul diante da possibilidade da Alca e do atrativo da negociação com a União Européia. ${ }^{20}$

As dificuldades encontradas nas últimas rodadas de negociações do Comitê de Negociações Biregionais do Mercosul com a União Européia, ocorridas a partir da Reunião de Brasília, em meados de agosto de 2004, até as do ocaso da Comissão Européia que deixou o mando em fins de 2004, demonstra perfeitamente a pertinência da assertiva anterior. Não apenas razóes de ordem estratégica geral, ou de afinidades culturais, ou as "brechas" táticas em relação às negociações da Alca podem ser utilizadas na evolução do processo negociador com os europeus. A defesa de interesses nacionais ou sub-regionais, como o fizeram os negociadores em Brasília, denotam mais maturidade, realismo e percepção de que $\mathrm{o}$ ativismo comercial tem que ser alicerçado em ganhos equilibrados e não em imposiçóes neocoloniais. $\mathrm{O}$ Brasil e seu parceiro estratégico no Mercosul - a Argentina (apesar da crise nas exportaçóes das geladeiras, fogões e carros) - parecem ter avançado essa percepção, que também se espraia para parte relevante da América do Sul.

\section{A força dos agentes subnacionais no comércio exterior do Brasil: aproximações comparadas e o caso do Estado do Ceará}

Apesar dos constrangimentos referidos na segunda parte desse estudo, há criatividade e movimento no plano subnacional. Em especial, os dirigentes dos governos dos estados da federação têm demonstrado alguma capacidade de agir via açóes concertadas perante ao poder central. A pressão política direta dos governadores na direção do Poder Executivo federal ou do Congresso Nacional vem sendo a forma mais explícita de agir das unidades subnacionais. A depender do quadro de coalizôes internas dos partidos na base de sustentação do governo nacional, vários governadores vêm aproveitando esse relacionamento para explorar brechas de "autonomia relativa" em relação à burocracia do governo federal.

\footnotetext{
${ }^{20}$ COSTA VAZ, Alcides, Tendências estruturais do Sistema Multilateral de Comércio sob a égide da OMC. In: ESTEVES, Paulo Luiz. Instituiçōes internacionais: segurança, comércio e integração, Belo Horizonte: Editora PUC-Minas, 2003, p. 277.
} 
Exemplos dessa forma de lobby dos governos não-centrais se multiplicam e se fazem presentes desde a década passada. $O$ governador Tasso Jereissati, do Estado do Ceará, no nordeste brasileiro, do mesmo partido político do ex-presidente Fernando Henrique Cardoso, soube aproveitar em grande medida sua posição de homem forte do PSDB e potencial candidato à sucessão de Cardoso, como um trunfo nas negociações voltadas para uma melhor inserção do estado nos financiamentos e comerciais do Brasil em fins da década passada e início da atual.

Em segundo lugar, vários governadores de estado têm utilizado suas viagens ou seus escritórios internacionais na forma de intervenção direta nas fontes financiadoras do comércio internacional. Nesse caso, via contato direto, constroem-se pontes "transsoberanas", formais ou informais, com outras fontes de poder de outros estados nacionais.

Destaca-se, nesse caso, a criação do escritório do Estado de Minas Gerais na Europa, com sede na França, pelo governador Itamar Franco, ex-presidente da República, no final da década passada, transformado em "balcão de negócios" dessa unidade subnacional em um país soberano. No caso de Itamar Franco, a iniciativa estava diretamente voltada para a competição e o conflito direto com os objetivos gerais e os métodos do poder central do governo nacional. ${ }^{21}$

Uma terceira dimensão a ser considerada é a geografia múltipla que impulsiona diferentes regiōes do país para certos enfoques na agenda comercial do Brasil. Se a logística dos estados do nordeste do Brasil se dirige prioritariamente para o contexto caribenho-europeu-africano, é natural que os estados do sul do Brasil estejam mais voltados para o contexto platino da América do Sul. Estudos recentes, como o de Wilson Almeida, demonstraram o quanto a geografia pesa no destino das exportações brasileiras. ${ }^{22}$ Estados da federação brasileira que possuíam uma geografia

\footnotetext{
${ }^{21}$ Vale lembrar que, nos marcos do federalismo centralista brasileiro, estaria ocorrendo uma certa "paradiplomacia" com limites constitucionais discutíveis e que rompe, informalmente, as restriçóes legais no que tange aos aspectos legais dos compromissos internacionais que advenham dessa forma de agir. Para o caso brasileiro, e de forma comparada com outros federalismos, é essencial ler a tese do Curso de Altos Estudos do Instituto Rio Branco (Ministério das Relações Exteriores) de José Vicente da Silva Lessa. Ver LESSA, José Vicente da Silva. A paradiplomacia e os aspectos legais dos compromissos internacionais celebrados por governos nãocentrais. Brasília: MRE, XVIL Curso de Altos Estudos, dezembro de 2002.

22 ALMEIDA, Wilson. Mercosul: efeitos da integração assimétrica. Goiânia: Editora e Espaço de Cultura Brasileira, 2003.
} 
privilegiada em relação ao Cone Sul, antes do Mercosul ser criado, conseguiram ampliar em termos reais o comércio exterior com os países do bloco sub-regional, mas não alteraram sua relação privilegiada de parceiros preferenciais dos países vizinhos. Ao mesmo tempo, "regiōes periféricas" do Mercosul, no interior de países como o Brasil, permaneceram com um comércio relativamente periférico em relação aos mesmos. ${ }^{23}$

A tabela II é bastante clara. Tanto no início, quanto no avanço tardio do Mercosul, as relaçóes entre as percentagens de participação por unidade subnacional (estados da federação) e por regiōes brasileiras permanecem quase as mesmas, entre o início e meados da década de 1990. Essa tendência se mantém ainda no início desta década.

\section{Tabela II}

Exportações brasileiras - valor e participação percentual (1992-1996)

Estados e regiões - Mercosul (milhões de dólares)

\begin{tabular}{l|l|l|l|l|l|l|l|l|l|l}
\hline Rio Grande do Norte & 2 & 0,0 & 3 & 0,0 & 2 & 0,0 & 2 & 0,0 & 4 & 0,0 \\
\hline Paraíba & 0 & 0,0 & 2 & 0,0 & 3 & 0,0 & 7 & 0,1 & 4 & 0,0 \\
\hline Pernambuco & 21 & 0,5 & 25 & 0,4 & 44 & 0,7 & 36 & 0,6 & 40 & 0,5 \\
\hline Alagoas & 0 & 0,0 & 0 & 0,0 & 12 & 0,2 & 0 & 0,0 & 8 & 0,1 \\
\hline Sergipe & 4 & 0,1 & 4 & 0,0 & 3 & 0,0 & 3 & 0,0 & 13 & 0,1 \\
\hline Bahia & 137 & 3,3 & 141 & 2,6 & 189 & 3,2 & 287 & 4,7 & 308 & 4,2 \\
\hline Norte & 56 & 1,3 & 75 & 1,4 & 41 & 0,7 & 53 & 0,8 & 63 & 0,8 \\
\hline Acre & - & - & 0 & 0,0 & - & - & 0 & 0,0 & 0 & 0,0 \\
\hline Rondônia & 1 & 0,0 & 2 & 0,0 & 2 & 0,0 & 2 & 0,0 & 3 & 0,0 \\
\hline Amazonas & 34 & 0,8 & 32 & 0,6 & 15 & 0,2 & 21 & 0,3 & 37 & 0,5 \\
\hline Pará & 20 & 0,5 & 38 & 0,7 & 21 & 0,3 & 26 & 0,4 & 21 & 0,3 \\
\hline Amapá & 0 & 0,0 & 1 & 0,0 & 2 & 0,0 & 2 & 0,0 & 1 & 0,0 \\
\hline Roraima & - & - & - & - & 0 & 0,0 & 0 & 0,0 & - & - \\
\hline Tocantins & - & - & - & - & - & - & - & - & 0 & 0,0 \\
\hline Sudeste & 3.009 & 73,6 & 3.750 & 70,0 & 4.103 & 70,0 & 4.123 & 68,4 & 4.902 & 67,6 \\
\hline São Paulo & 2.153 & 52,6 & 2.707 & 50,5 & 3.046 & 52,0 & 3.160 & 52,4 & 3.949 & 54,4 \\
\hline Rio de Janeiro & 270 & 6,6 & 365 & 6,8 & 377 & 6,4 & 317 & 5,2 & 308 & 4,2 \\
\hline Espírito Santo & 58 & 1,4 & 77 & 1,4 & 131 & 2,2 & 157 & 2,6 & 120 & 1,6 \\
\hline Minas Gerais & 526 & 12,8 & 599 & 11,1 & 548 & 9,3 & 487 & 8,1 & 524 & 7,2 \\
\hline Sul & 793 & 19,4 & 1.260 & 23,5 & 1.353 & 23,1 & 1.363 & 22,6 & 1.725 & 23,7 \\
\hline Paraná & 225 & 5,5 & 362 & 6,7 & 360 & 6,1 & 337 & 5,6 & 451 & 6,2 \\
\hline Santa Catarina & 192 & 4,7 & 290 & 5,4 & 288 & 4,9 & 315 & 5,2 & 377 & 5,2 \\
\hline Rio Grande do Sul & 375 & 9,1 & 607 & 11,3 & 704 & 12,0 & 709 & 11,7 & 895 & 12,3 \\
\hline Fonte: Mendes & & & -137 & \\
\hline
\end{tabular}

Fonte: Mendes, C.C. Ipea: TD 510, 1997 (elaborada por Wilson Almeida)

23 Wilson Almeida em sua obra extraordinária sobre as assimetrias subnacionais no Mercosul. Ver ALMEIDA, Wilson, op. cit. p. 249-262. 
Em quarto lugar, e agora de forma mais consistente, os governos subnacionais que compõem os estados da federação brasileira têm se esmerado no mecanismo de criação de agências, assessorias e secretarias de governo com atribuições no campo da internacionalização de suas estratégias de desenvolvimento. Alguns governos locais - particularmente capitais e grandes cidades de estados da federação mais proeminentes no comércio externo - também criaram tais aparatos, como é nítido no caso paulistano.

Registre-se o grau de competência técnica média que se observa nessas operativas, pequenas máquinas articuladoras dos interesses federativos no comércio exterior. Açóes e textos lidos evidenciam a preparação desses quadros formados, em alguns casos, com o adensamento de novas carreiras de cursos como bacharelados e cursos de pós-graduação em relaçōes internacionais e comércio exterior. ${ }^{24}$ Desnecessário mencionar, tendo em vista a densidade da participação dessa unidade da federação no comércio exterior do Brasil, o Estado de São Paulo.Também se pode dizer do aprimoramento dessas máquinas flexíveis e laboriosas no Nordeste, em estados como o Ceará e a Bahia, ou mesmo no Centro-Oeste, como Goiás e Mato Grosso.

Dossiês bem elaborados são organizados por tais assessorias e secretarias internacionais dos estados da federação, consubstanciando opções táticas e estratégicas dessas unidades subnacionais em suas próprias missões internacionais. Governadores viajam, muitas vezes, com mais objetividade e mais bem preparados para a negociação de interesses comerciais, que membros do governo central em suas diligências internacionais.

A transformação operada por essas modificações ainda não foi suficientemente atualizada. Dissertaçóes, teses acadêmicas e diplomáticas vêm tratando de recolher a dinâmica de tais agências, tanto na esfera dos estados da federação quanto das municipalidades. ${ }^{25}$ Dessa experiência

\footnotetext{
${ }^{24}$ Apenas para mencionar dois documentos extraordinários: CEARÁ, Gabinete do Governador, Assessoria Internacional, Subsídios à Missão do Estado do Ceará à China, Fortaleza, agosto de 2004; Idem, Subsídios à Missão do Estado do Ceará a Angola, Fortaleza, fevereiro de 2004.

${ }^{25}$ Um dos mais recentes trabalhos é a tese doutoral de Gilberto Marcos Antonio Rodrigues. Ver RODRIGUES, Gilberto M.A. Política externa federativa: análise de ações internacionais de estados e municípios brasileiros. São Paulo: Pontifícia Universidade Católica de São Paulo, junho de 2004.
} 
recente, no campo do comércio exterior, sobressaem-se alguns relevantes registros.

$\mathrm{O}$ primeiro e mais claro registro que se pode fazer da atuação dos agentes externos dos governos subnacionais brasileiros é que eles estão, de facto, ainda que não de jure, atuando de forma crescente em busca de "autonomia relativa". A despeito de limites jurídicos internacionais e internos que constrangem sua ação legal, em particular, os estados da federação têm se mostrado criativos e ativos.

O segundo registro é que nem sempre esse movimento dos entes federativos na direção do exterior tem sido feito em consonância com os ditames do poder central. Acompanhando posiçóes que fazem lembrar os governos provinciais canadenses dos anos 80 , quando favoreceram produtores locais na venda externa de vinhos, contra compromissos assumidos pelo governo central canadense no então Gatt, ou de governadores norte-americanos que proibiram investimentos estrangeiros em alguns setores da produção, o Brasil, da década de 1990, assistiu a guerra fiscal, na qual os governadores de estado protagonizaram verdadeira "quebra de braço" com o governo central no sentido do acesso a novos investimentos internacionais para empreendimentos internos.

Dessa forma, no caso brasileiro, nem sempre as relações entre o poder central e os governos subnacionais têm se pautado pela cooperação. Há uma crítica crescente dos governadores de estado no sentido de que a receita estadual efetiva vem se reduzindo nos últimos anos, inclusive diante do aumento das pressões fiscais geradas pela própria União. Ações de inconstitucionalidade foram impetradas por alguns governadores na própria corte suprema, o Supremo Tribunal Federal.

O terceiro registro é a emergência gradual do nordeste brasileiro na agenda do comércio exterior do Brasil. Região historicamente periférica na pauta exportadora, a região nordestina vem demonstrando capacidade de mobilização de recursos na direção da interação do meio nacional ao internacional nos últimos anos. O Estado da Bahia inovou ampliando a cooperação internacional com países como o Chile, os Estados Unidos, a Itália, a Argentina, a Coréia do Sul e Portugal, além de ter incluído países da Ásia, como a Malásia e a Indonésia na cooperação agroflorestal. O Centro Internacional de Negócios da Bahia (Promo) - vem sendo um agente fundamental nessa mobilização de esforços. O Estado de 
Pernambuco abriga em seu território a representação nordestina do Escritório de Representação do Itamaraty no Recife. A ampliação de ações dessa unidade subnacional vem ocorrendo especialmente com a Holanda, França e Alemanha.

A mais dinâmica unidade federativa no nordeste brasileiro, no entanto, vem sendo o Estado do Ceará. Chama a atenção, o movimento liderado pela Assessoria de Assuntos Internacionais daquela unidade subnacional nos últimos dez anos, durante os oito anos do governo de Tasso Jereissati e os quase dois anos do governador Lúcio Alcântara, no sentido de adensar as relações externas daquela unidade da federação. A diversificação de parceiros na Europa (a envolver países como Portugal, Itália, Espanha, França, Alemanha e Rússia), na América Latina (em especial com a Argentina, Cuba, México e Chile), e mesmo na Ásia (como a China), além dos Estados Unidos, vem sendo a marca desses governos.

Recentemente, sob a coordenação de Nelson Bessa, chefe da Assessoria Internacional daquela unidade federativa, a missão se dirigiu à China, à Coréia do Sul e à África, com ênfase ao Cabo Verde e Angola. Essas pontes asiáticas e africanas, mas particularmente atlânticas, especialmente ante a ligação aérea de Fortaleza com Praia (Cabo Verde), têm propiciado a ampliação de exportação para parceiros, até então, pouco imaginados como mercados potenciais do Brasil.

A tradução desse esforço, mesmo nos limites da legalidade jurídica, já é notada pelos os dados e análises que são agora apresentados. $\mathrm{O}$ Ceará passou a ter uma inserção comercial internacional inimaginável sem essa inédita articulação, quase sempre realizada sem grande apoio da burocracia do governo central, muito embora de forma cooperativa a ela. Em muitos casos, essa cooperação é apenas formal ou política para evitar eventuais retaliações ou "invejas" institucionais.

Nesse sentido, seguindo a tendência de internacionalização gradual, que vem desde meados da década passada, e mesmo a despeito da deficiente promoção comercial do estado nacional, as exportações cearenses reagiram mais fortemente do que as exportações do país em seu conjunto. O Ceará registrou um expressivo aumento nas suas exportações (em dólares correntes) entre 1991 e 2002, a uma taxa anual de $6,6 \%$, superando a média de crescimento das exportaçóes 
brasileiras ( $6 \%$ a.a), tudo isso com expansão da base exportadora (de apenas cinqüenta empresas, em 1991, para 260 em 2002) e uma sensível diversificação na pauta de produtos manufaturados, de maior valor agregado e/ou conteúdo tecnológico. Com efeito, em 1991, os produtos manufaturados responderam por apenas $28,2 \%$ da pauta estadual, passando a $46 \%$, em 2002 , e chegando a $51,6 \%$ em 2003 , próximo, portanto, da média brasileira.

Em 2003, a tendência de expansão exportadora no Ceará parece ter atingido novo patamar, acusando um incremento de $39,8 \%$ no acumulado do ano (cerca de US\$ 761 milhões), sobre idêntico período do ano anterior, bem acima da média de crescimento brasileira, que foi de 21,1\%. Esse movimento de expansão exportadora superior a média nacional ocorreu em 17 estados da Federação, cabendo ao Ceará a quinta maior taxa de crescimento, atrás somente de Tocantins (181,2\%), Goiás $(69,8)$, Paraíba (43,2\%) e Acre $(39,9 \%)$, deslocando o estado para a $12^{\text {a }}$ posição no ranking dos maiores estados exportadores e respondendo por pouco mais de $1 \%$ das vendas externas totais do Brasil.

Cabe salientar que o desempenho cearense no ano de 2003, com aumento de praticamente $40 \%$ nas exportações estaduais, se compara favoravelmente aos campeões do crescimento exportador no país, uma vez que superou o crescimento da Bahia (35,2\%) e somente ficando atrás da Paraíba $(43,2 \%)$ e de Goiás $(69,8 \%)$, este último beneficiado pelas condições excepcionalmente favoráveis de seu agronegócio. Estados menores (como Acre e Tocantins, na Amazônia brasileira) lograram aumentar ainda mais suas exportaçōes, mas sua base estatística é incipiente para merecer análise comparativa. No mesmo intervalo, o desempenho exportador do Nordeste como um todo foi de $31,2 \%$, ao passo que no Sudeste foi de apenas 16,2\%.

Do lado das importações, a desaceleração econômica durante o ano fez as compras no exterior recuaram $15 \%$ em 2003, atingindo o patamar de US \$ 540,7 milhōes. Em contraste, as importações brasileiras cresceram $2,16 \%$ no ano. 


\section{Tabelas III, IV e V}

Comércio Exterior do Ceará, 1991-2003

\begin{tabular}{l|c|c|r|r|c|c}
\cline { 2 - 7 } & \multicolumn{5}{c|}{ CEARÁ } & \multicolumn{2}{c}{$\%$ CE/BR } \\
\hline Ano & Exportações & Importações & \multicolumn{1}{c|}{ Saldo } & Intercâmbio & Exportações & Importações \\
\hline $\mathbf{1 9 9 1}$ & 270.419 & 164.618 & 105.801 & 435.037 & 0,86 & 0,78 \\
\hline $\mathbf{1 9 9 2}$ & 303.691 & 238.615 & 65.076 & 542.306 & 0,85 & 1,16 \\
\hline $\mathbf{1 9 9 3}$ & 274.825 & 387.957 & -113.132 & 662.782 & 0,71 & 1,54 \\
\hline $\mathbf{1 9 9 4}$ & 334.861 & 522.728 & -187.867 & 857.589 & 0,77 & 1,58 \\
\hline $\mathbf{1 9 9 5}$ & 352.131 & 646.954 & -294.823 & 999.085 & 0,76 & 1,29 \\
\hline $\mathbf{1 9 9 6}$ & 380.434 & 813.469 & -433.035 & 1.193 .903 & 0,80 & 1,52 \\
\hline $\mathbf{1 9 9 7}$ & 353.043 & 681.904 & -328.861 & 1.034 .947 & 0,67 & 1,14 \\
\hline $\mathbf{1 9 9 8}$ & 355.246 & 605.950 & -250.704 & 961.196 & 0,69 & 1,05 \\
\hline $\mathbf{1 9 9 9}$ & 371.206 & 573.468 & -202.262 & 944.674 & 0,77 & 1,17 \\
\hline $\mathbf{2 0 0 0}$ & 495.098 & 717.718 & -222.620 & 1.212 .816 & 0,90 & 1,29 \\
\hline $\mathbf{2 0 0 1}$ & 527.051 & 623.476 & -96.425 & 1.150 .527 & 0,91 & 1,12 \\
\hline $\mathbf{2 0 0 2}$ & 543.902 & 631.206 & -87.304 & 1.175 .108 & 0,90 & 1,34 \\
\hline $\mathbf{2 0 0 3}$ & 760.927 & 635.910 & 125.017 & 1.396 .837 & 1,04 & 1,32 \\
\hline
\end{tabular}

Dados: MDIC

Elaboração: Assessoria Internacional

Participação do CE no Comércio Exterior brasileiro, 1991-2003

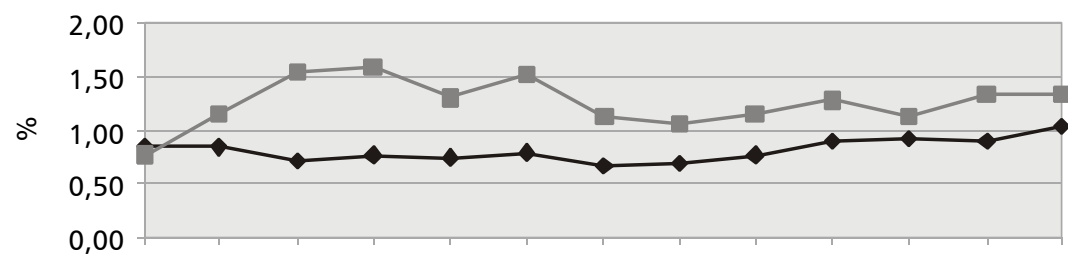

1991199219931994199519961997199819992000200120022003

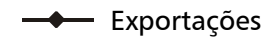

- Importações

\section{Comércio Exterior do Ceará, 1991-2003}

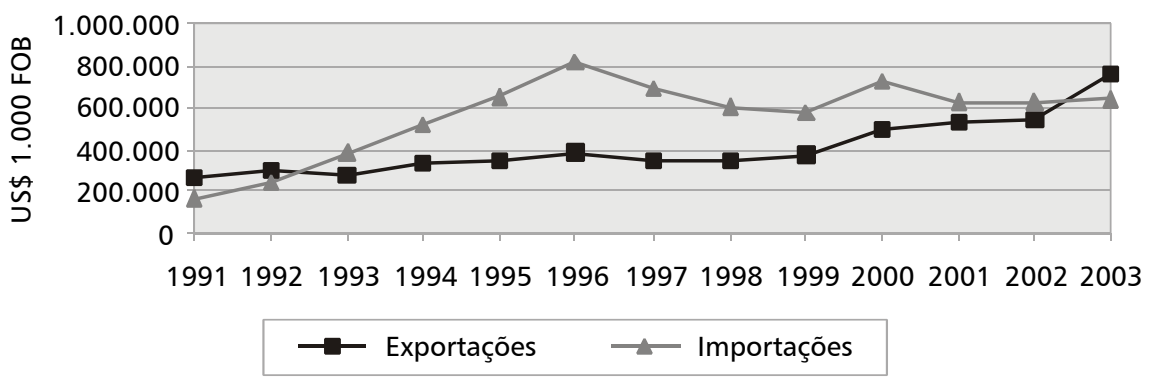

Fonte: Assessoria Internacional, Estado do Ceará 
Em relação à captação de recursos externos oficiais, a carteira de projetos internacional do Ceará é uma das maiores entre os estados brasileiros. A continuidade da gestão fiscal austera tem-lhe proporcionado a credibilidade necessária para contratar empréstimos externos com as agências multilaterais e bilaterais. No ano de 2003, em que pesem as dificuldades da conjuntura macroeconômica sobre as finanças dos estados, o Ceará logrou captar US \$265,9 milhões em novas operaçôes de crédito, sendo uma com o KfW (\$ 8,7 milhōes), uma com o Bird (US\$ 64,1 milhões), duas com o BID (no total de US\$ 178 milhões), e outra com o MLW Intermed, entidade privada alemã (US\$ 17 milhões). Cabe ressaltar que os recursos captados, ora referidos, encontram-se em estágio avançado de negociação, devendo ser contratados e desembolsadas no decurso de 2004 e nos anos seguintes.

Desse modo, a economia cearense manteve, em 2003, o ritmo de inserção dos anos anteriores nos fluxos mundiais de comércio, investimento e financiamento, deixando para trás o tradicional isolamento do estado, exibindo promissores sinais de competitividade de seu aparelho produtivo e aparentes vantagens comparativas na atração de investimentos. Ante eventual retomada consistente do crescimento nacional, o Ceará parece ter razões para crer que a continuidade de incremento das exportações, do turismo estrangeiro e dos investimentos externos, contribuirão para a geração de renda e emprego e para acelerar a transformação esperada no perfil socioeconômico do estado "alencarino". Seria um caso interessante de versão brasileira do proposto conceito de federalismo social.

\section{Conclusões}

Se no mundo existem cerca de quase três dezenas de países com características abrangentes do sistema federativo, é verdade que o Brasil tem uma das mais centralizadas formas de ação externa do Estado. Ao contrário da Alemanha, Estados Unidos, Austrália e Suíça, a formação histórica do federalismo esgarçado no Brasil construiu uma metodologia centralista e restritiva de federalismo no que se refere à política externa e a de comércio exterior. Se na maioria dos casos, essas políticas oscilam entre certa "autonomia relativa" e a mais "absoluta subordinação à União", o caso brasileiro está certamente para a segunda inclinação do pêndulo. 
As mudanças econômicas, políticas, sociais e tecnológicas das últimas décadas fizeram emergir novas realidades que demandam atitudes e recursos gerenciais nem sempre presentes nas estruturas tradicionais das instituições governamentais. O Brasil, nesse assunto, tem se mostrado mais conservador que a grande gama de Estados federativos no que se refere à capacidade de ação dos governos subnacionais na gestão do comércio exterior. A centralidade da burocracia itamaratiana, associada a outros setores governamentais como o Ministério do Desenvolvimento, Indústria e Comércio Exterior, ademais da Camex, controlam e dirigem os fluxos dominantes e a política de apoio às exportações, mesmo envolvendo áreas de ação gerencial dos estados da federação.

Essa relação não é estática. Ela opera de forma dinâmica no tempo, na geografia múltipla bem como na diversidade de interesses em jogo e nas possibilidades que se criam ante o poder relativo de cada unidade subnacional. Se São Paulo participa com quase um terço das exportações do país, e se a concentração industrial mais expressiva no país também coincide com essa unidade da federação, é natural e racional o desenvolvimento de expertise e a abertura de brechas de "autonomia relativa” no estado mais desenvolvido economicamente na federação. É igualmente compreensível a inserção comercial internacional de governos subnacionais como o caso do Estado do Rio Grande do Sul, incrustado na fronteira brasileira mais sensível do Mercosul.

Para comentar o tema da assimetria interna na distribuição dos dividendos do acesso ao mercado externo, vale lembrar o seminal estudo de Cassiolato e Lastres:

Contrariamente à visão mais ou menos difundida sobre a hipotética internacionalizção dos esforços e resultados do desenvolvimento científico e tecnológico, os dados e análises atualmente disponíveis indicam: (i) uma marcante concentração do espaço econômico onde as informações e conhecimentos são produzidos e circulam, além de (ii) uma concentração nitidamente nacional dessas e outras atividades consideradas estratégicas. ${ }^{26}$

${ }^{26}$ CASSIOLATO, J.E; LASTRES, Helena. Globalização \& inovação localizada: experiência de sistemas locais no Mercosul. Brasília: MCT-IBICT, 1999, 17p. 
Ex positis, o problema se põe, no Brasil, para os estados menos expressivos do ponto de vista do PIB nacional e que estão construindo estruturas negociais externas com vistas a melhor participação do ativismo comercial do Brasil nos últimos anos. O caso avaliado neste estudo, do governo do Estado do Ceará, demonstra o quanto novas oportunidades, mesmo sob o constrangimento da concorrência interna dos estados mais ricos, estão sendo exploradas.

Vale lembrar que, de forma crescente, no âmbito dos estados nacionais, torna-se cada vez mais tênue a separação entre política externa, de segurança e de prestígio, e aquelas outras matérias de caráter econômico, cultural ou social. O emaranhado dessas questóes deslocou as relações internacionais para a inclusão de atores que oferecem mais confiança para o poder central do Estado que parte das chamadas organizações não-governamentais. As conseqüências da interdependência global vêm possibilitando a ampliação da confiança da ação cooperativa entre o poder central e os governos subnacionais. $\mathrm{O}$ caso brasileiro exemplifica, a seu modo próprio, essa evolução tímida. Mas que necessita avançar, de forma célere, na fundação do conceito mesmo de federalismo social, aqui proposto. E nada disso será possível sem a introdução da dimensão logística do Estado nacional, conforme também discutimos neste estudo.

Medidas urgentes, a evidenciar a vontade de construção de um novo paradigma que melhor articule o federalismo brasileiro com a modernização empreendida pela própria política e comércio exterior do país, são necessárias. Três ações podem ser prontamente encaminhadas pelo governo central, em franca articulação com os interesses das unidades subnacionais.

A primeira refere-se ao reforço que se faz necessário no acompanhamento de experiências subnacionais que demonstram êxito na operação externa. As articulações internacionais dos entes subnacionais adensaram-se no curto prazo recente, sem uma visão de conjunto dos grandes interesses nacionais. Ainda falta, no Brasil, um repertório crítico dessas experiências, seja relativo às ações dos grandes, médios e pequenos estados da federação, seja em relação aos grandes municípios, especialmente das capitais economicamente mais integradas ao capitalismo global. 
Os dados apresentados neste estudo relativos ao Estado do Ceará demonstram que há novidades que não são conhecidas ou tratadas no âmbito da high politics internacional do Brasil. O entrelaçamento dessas duas dimensões - a da política exterior e do comércio exterior - no envolvimento das unidades subnacionais e interesses socialmente constituídos em torno da idéia de federalismo social, ainda é uma matéria de grande invisibilidade nos estudos e na formação do processo decisório da política externa encetada pelo governo federal. Outros estados federativos avançaram mais nessa matéria. O Brasil pode estar ficando démodé no tratamento de relevante dimensão estratégica para um país continental com interesses múltiplos e geografia complexa na cena internacional.

Em segundo lugar, a diplomacia dos governadores de Estado necessita operar em maior consonância com a diplomacia do Estado federal e vice-versa. Área sensível, animadora de crises permanentes do federalismo inconcluso no Brasil, este é um campo que será necessária maior coordenação política. Uma medida imediata nesta direção seria a incorporação, no processo negociador externo do Estado nacional, de representantes dos entes federativos. Por múltiplas razões, geográficas inclusive, alguns estados da federação estão mais envolvidos em temas que lhes são mais atinentes, mas não são sempre convidados a opinar na construção de políticas públicas ou externa com impacto na sua territorialidade menor.

Esta é uma deficiência que necessita ser suprida imediatamente. Há, é certo, alguns avanços nas relações externas dos estados do Sul do Brasil com seu entorno "mercosulino" mas o mesmo não se pode dizer dos estados amazônicos em relação ao seu meio sul-americano. Ou mesmo de estados do Nordeste do Brasil em relação ao meio afro-caribenho, sem falar da logística que os impulsiona a Europa e aos Estados Unidos. Permanece a carência, nas caravanas presidenciais de visitas a países estratégicos para o comércio externo do Brasil, da presença de governadores de estados relevantes para as negociações em curso. Neste caso o Brasil está desperdiçando capital político que poderia ser aproveitado de maneira mais salutar.

Em terceiro e último lugar, será necessário aparelhar melhor o Itaramaty e os entes subnacionais com operadores para estes novos marcos das relações externas federativas. $\mathrm{O}$ conservadorismo corporativo do Itamaraty, embora muito positivo no que se refere aos grandes temas de 
interesse externo do Brasil, não tem demonstrado capacidades operativa e cooperativa para as novas possibilidades que se ensaiam. Burocracia excessiva e centralismo, nesta matéria, são nefastos. $\mathrm{O}$ comércio opera em um espaço de tempo mais breve que o tempo dilatado da política internacional. Uma nova formação de quadros, mais ambientados com esses novos desafios, necessita ser pensada. Há também, neste caso, experiências internacionais que merecem ser avaliadas, não para copiá-las, mas para verificar sua pertinência e comparar com a nossa situação.

Outubro de 2004

\section{Bibliografia}

ABRÚCIO, Fernando \& COSTA, Valeriano. Reforma do Estado e o contexto federativo brasileiro. São Paulo: Fundação Konrad Adenauer, 1998.

AFFONSO, Ruy B.; SILVA, Pedro Luiz Barros (org.). A Federação em Perspectiva: ensaios selecionados. São Paulo: FUNDAP, 1995.

ALMEIDA, Wilson. Mercosul: Efeitos da integração assimétrica. Goiânia: Editora e Espaço de Cultura Brasileira, 2003.

BOWIE, Robert \& FRIEDRICH, Carl. Études sur le fédéralisme. V.1. Paris: Librarie Générale de Droit et de Jurisprudence, 1960.

BURGESS, M. \& GAGNON, A. (ed). Comparative Federalism and Federation Toronto: University of Toronto Press, 1993.

CAMARGO, Aspásia. A federação acorrentada. Rio de Janeiro: FGV/Centro de Pesquisa e Documentação de História Contemporânea do Brasil, 1993.

CASSIOLATO, J. E \& LASTRES, Helena, Globalização \& Inovação localizada: experiência de sistemas locais no Mercosul. Brasília: MCT-IBICT, 1999, 17p.

CERVO, Amado L. Relações Internacionais do Brasil: um balanço da era Cardoso. Revista Brasileira de Politica Internacional, ano 45, v.1. Brasília: Instituto Brasileiro de Relações Internacionais. 2002, p. 5-35.

CERVO, Amado. Política exterior e relaçōes internacionais do Brasil: enfoque paradigmático. Revista Brasileira de Política Internacional, ano 46, v. 2. Brasília: Instituto Brasileiro de Relações Internacionais. 2003, p. 22. 
COSTA VAZ, Alcides. Tendências estruturais do Sistema Multilateral de Comércio sob a égide da OMC. In: ESTEVES, Paulo Luiz. Instituiçôes internacionais: segurança, comércio e integração, Belo Horizonte: Editora PUC-Minas, 2003, p. 227.

DEHOUSSG, Renaud. Federalisme et relations internacionales. Bruxelles: Bruylant, 1991.

DUCHACEK, Ivo D. Comparative Federalism - The Territorial Dimensions of Politics. New York: Holt, Rinehart and Winston, Inc., 1970.

DUCHACEK, Ivo. Perforated Sovereignties: Towards a Typology of New Actors in International Relations. In: Federalism and International Relations: the role of subnational units/ Ed: Hans MICHELMANN \& Panayotis SOLDATOS. Oxford: Claredon Press, 1990, p. 1-33.

ELAZAR, Daniel J. Exploring Federalism. Tuscaloosa: University of Alabama Press, 1987.

FARIAS, Déborah Barros Leal. Os Estados-membro no Federalismo Brasileiro. Idéias \& Debate, n.20, agosto de 2000.

FARIAS, Déborah Barros Leal. Federalismo e Relaçôes Internacionais, 2000. Dissertação de mestrado - Programa de Pós-Graduação em Relações Internacionais, Universidade de Brasília, Brasília.

FIORI, José Luiz. O Federalismo diante do Desafio da Globalização. In: $A$ Federação em Perspectiva: Ensaios selecionados. São Paulo: Fundap/Unesp (Série Federalismo no Brasil), 1995.

FOSSAS, E.; REQUEJO, F. (ed.). Asimetría Federal Y Estado PLURINACIONAL. El debate sobre la acomodación de la diversidad en Canadá, Bélgica y España. Madrid: Trotta, 1999.

GLOSSOP, Ronald J. World Federation? A Critical Analysis of Federal World Government. Jefferson (NC): McFarland \& Company, Inc. 1993.

HOCKING, Brian. Localizing Foreign Policy: Non-central Governments and Multilayered Diplomacy. NY: Saint Martin'Sim Press, 1993.

MICHELMANN, Hans J. and Soldatos, Panayotis (org). Federalism and International Relations - the Role of the Subnational Units. Oxford: Claendon Press, 1990. 
MITRA, S. K. (org.) Subnational Movements in South Asia. Boulder (Colorado): Westview Press, 1966.

PRAZERES, Tatiana. Federalismo e Relaçôes Internacionais - a atuação dos Estados brasileiros no âmbito externo, 2000. Dissertação - Universidade do Vale do Itajaí, Itajaí.

REQUEJO, Ferrán. Cultural Pluralism, Nationalism and Federalism. A Revision of Democratic Citizenship. in: Plurinational States. European Journal of Political Research, 35,2, 1999, p. 255-286.

RODRIGUES, Gilberto M.A. Política externa federativa: análise de açôes internacionais de Estados e Municípios brasileiros. São Paulo: Pontifícia Universidade Católica de São Paulo, 2004.

SARAIVA, José Flávio S. (ed). Foreign Policy and Political Regime. Brasilia: IBRI, 2003.

Argentina e Brasil: um novo ensaio estratégico. Relaciones Internacionales. 25, IRI-UNLP, diciembre-mayo 2004, p. 141-148.

. Lula, África e OMC na crítica de direita. O Povo, 8 de agosto de 2004, p. 34 .

Política exterior do Governo Lula: o desafio africano. Revista Brasileira de Política Internacional, ano 45, v.2. Brasília: Instituto Brasileiro de Relaçôes Internacionais, 2002, p. 5-25.

SOLDATOS, Panayotis. Na Explanatory Framework for the Study of Federated States as Foreign-policy Actors. In: Federalism and International Relations: the role of subnational units. Ed: Hans MICHELMANN e Panayotis SOLDATOS. Oxford: Claredon Press, 1990, p. 34-53.

TORRES, João Camilo de Oliveira. A Formação do Federalismo no Brasil. São Paulo: Companhia Editora Nacional, 1961.

VIGEVANI, Tullo et allia. A dimensão subnacional e as Relações Internacionais. São Paulo: Ed. UNESP, 2004.

WATTS, Ronald L. Comparing Federal Systems in the 1990s. Kingston and Montreal: Institute of Intergovernmental Relations, Queen's University Press, 1997. 


\section{Resumo}

O artigo examina o processo de inserção das entidades federativas no cenário do comércio internacional. Para tanto, faz uma análise das relações entre o Estado federativo do Brasil e as relações internacionais do mesmo, com vista ao comércio exterior. Ressalta a nova conjuntura, na qual se faz mister a participação dos Estados-membro articulados com o governo central brasileiro. Destaca o papel do Nordeste, em especial o Ceará, nesse novo contexto econômico.

\section{Abstract}

This article examines the process whereby federation members participate in international trade. To this end, it surveys relations within the Brazilian Federative State and the latter's international relations linked to foreign trade. The article stresses the new circumstances, which requires coordination between federation members and the Brazilian central government. It also points out the role of the Northeast and of the state of Ceara in particular in this new economic context.

Palavras-chaves: Comércio Exterior; Brasil; Federalismo

Key words: Foreign Trade; Brazil; Federalism. 